On the Shoulders of Giants 



\section{UMBERTO ECO}
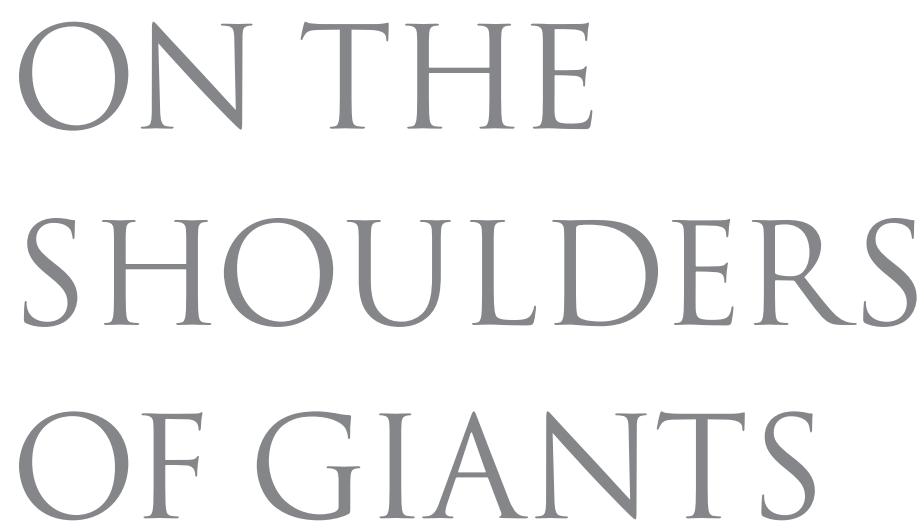

Translated from the Italian by Alastair McEwen

THE BELKNAP PRESS OF HARVARD UNIVERSITY PRESS

Cambridge, Massachusetts • 2019 
Printed in the United States of America

English translation copyright (C) 2019 La Nave di Teseo Editore, Milano

Originally published in Italian as Sulle spalle dei giganti : lezioni alla Milanesiana, 2001-2015

Copyright $\odot 2017$ La Nave di Teseo Editore, Milano

Published in the United States by Harvard University Press, 2019

Jacket art: Antoine Revoy

Jacket design: Annamarie McMahon Why

9780674242272 (EPUB)

9780674242289 (MOBI)

9780674242265 (PDF)

Library of Congress Cataloging-in-Publication Data is available from loc.gov ISBN: 978-0-674-24089-6 (alk. paper) 
We are dwarfs on the shoulders of giants.

-BERNARD OF CHARTRES 
